\title{
Characteristics of 15-Year-Old Students Predicting Scientific Literacy Skills in Turkey
}

\author{
Ergül Demir ${ }^{1}$ \\ ${ }^{1}$ Department of Measurement and Evaluation, Ankara University, Ankara, Turkey \\ Correspondence: Ergül Demir, Department of Measurement and Evaluation, Ankara University Cebeci Campus \\ 06590 Ankara, Turkey. Tel: 90-312-363-3350. E-mail: erguldemir@ankara.edu.tr
}

Received: January 22, 2016

Accepted: February 27, 2016 Online Published: March 27, 2016

doi:10.5539/ies.v9n4p99

URL: http://dx.doi.org/10.5539/ies.v9n4p99

\begin{abstract}
Since 2003, Turkey regularly participates in PISA. According to the PISA 2012 results, 15 -year-old students in Turkey performed below both OECD countries and participating countries. Defining the relations between students' characteristics and their scientific literacy skills is thought to provide deeper understanding for the nature of this situation in Turkey. The main aim of this study was to construct a significant multivariate model with secondary level structural equating modelling which includes relations between students' characteristics and their scientific literacy performance by using PISA 2012 Turkey data. Also, according to this model, it was aimed to define and interpret the predictive level of these characteristics to the scientific literacy skills of students. This study was designed as a basic research and secondary level analyses were conducted on PISA 2012 Turkey student questionnaire data. PISA 2012 Turkey sample was composed of 4.848 students. A secondary-level structural model was constructed by using PISA data. Limitations of the model, best predictor of scientific literacy skills were 'socio-economic status'. Students' 'opinions for teacher' shows negative correlation with scientific literacy skills. Students' 'attitudes for school' have low but positive correlation with scientific literacy skills. Among indicators, best predictor of scientific literacy skills is 'home possessions'. It is followed by 'index of economic, social and cultural status' and 'wealth'. Lowest predictors among indicators are 'attitude towards school: learning outcomes', 'attitude towards school: learning activities' and 'sense of belonging to school' respectively. All these variables are positively correlated with scientific literacy skills.
\end{abstract}

Keywords: PISA 2012 Turkey, scientific literacy, structural equation modelling

\section{Introduction}

Although not everyone agrees what that means, 'scientific literacy' becomes widely used term in science education since at least 1950. Considering the historical origins, depending on "the explosive developments in technology and concerns about national security" the science education was needed to re-define after World War II. "The goals of science teaching for general education purposes within this new environment came to be called scientific literacy" (DeBoer, 2000). Understanding the challenges of science education provides new opportunities in the context of scientific literacy (McFarlane, 2013).

It is obvious that there is a close relationship between science and technology. Hence, 'scientific literacy' and 'technological literacy' have the same meaning for most of us. These metaphorical terms represent two points of views. According to these views, science literacy refers to (1) the centre for knowledge of science, (2) the society usefulness (Halbrok \& Rannikmae, 2009).

Among many definitions, OECD sets out to define scientific literacy in the context of future adult life not just in education. Also this approach includes different points of views mentioned above. As an international and longitudinal study by conducting OECD, in The Programme for International Student Assessment (PISA), scientific literacy is defined different ways. But, these definitions are close to each other:

Scientific literacy is the capacity to use scientific knowledge, to identify questions and to draw evidence-based conclusions in order to understand and help make decisions about the natural world and the changes made to it through human activity (OECD, 1999, p .60). 
...the capacity to use scientific knowledge, to identify questions and to draw evidence-based conclusions in order to understand and help make decisions about the natural world and the changes made to it through human activity (OECD, 2003, p. 133)

....an individual's scientific knowledge and use of that knowledge to identify questions, to acquire new knowledge, to explain scientific phenomena, and to draw evidence-based conclusions about science-related issues, understanding of the characteristic features of science as a form of human knowledge and enquiry, awareness of how science and technology shape our material, intellectual, and cultural environments, and willingness to engage in science-related issues, and with the issues of science, as a reflective citizen (OECD, 2009a, p. 14).

...the ability to engage with science-related issues, and with the ideas of science, as a reflective citizen (OECD, 2013a, p. 7).

According to these definitions set out in the PISA, it is understood that scientific literacy relates to the ability to think scientifically and to use scientific knowledge and processes to understand the world. Moreover, scientific literacy includes the participation in decision-making processes effectively.

A scientifically literate person is expected to engage in some higher order thinking skills or competencies, like 'explain phenomena scientifically', 'evaluate and design scientific enquiry' and 'interpret data and evidence scientifically' (OECD, 2013a). It is possible that scientific literacy skills should be observed indirect way and predicted by considering these cognitive characteristics. On the other hand, it is well-known that there are significant correlations between scientific skills and students' characteristics like socio-economic status, educational level of parents, attitudes, opinions and etc. (An1l, 2009, 2011; Atwater, Wiggins, \& Gardner, 2006; Ceylan \& Abac1, 2013; Luu \& Freeman, 2010; OECD, 2009b; Özer \& Anıl, 2011; Watters \& Ginns, 2000). These researches show that students' characteristics are possible to be significant predictors of scientific literacy skills. However, it is seen that just few characteristics or variables are be able to consider in such kind of models to explain the relationships between the specific student characteristics and scientific literacy. But, it is obvious that there is a need for more detailed researches to understand the nature of scientific literacy. At this point, PISA provides solutions and advantages with their large-scale assessment framework.

PISA is a worldwide study by the Organisation for Economic Co-operation and Development (OECD) in member and non-member nations of 15-year-old students' performance on reading skills and mathematics literacy and science literacy. It was first performed in 2000 and then repeated every three years. In each study, one of these three areas is determined main domain. PISA 2012 was the fifth survey of the PISA. In PISA 2012, nearly 510000 students around age 15 in 65 countries and economies were tested. 34 of these countries and economies was the member of OECD (OECD, 2014a).

In PISA studies, different measurement tools are used to collect data about student characteristics related with the performance and forming the background of performance. Student questionnaire is one of these tools. Student questionnaire is a well-structured tool in terms of psychometrics. It provides important information about students' characteristics which are possible to correlate with scientific literacy and predicting scientific literacy (OECD, 2014a).

Since 2003, Turkey regularly participates in PISA. According to the PISA 2012 results, 15-year-old students in Turkey showed a success close to the average in scientific literacy. However, they performed below both OECD countries and participating countries. Most of the students are located on the first and second proficiency levels in scientific literacy (OECD, 2014b). Defining the relations between students' characteristics and their scientific literacy skills is thought to provide deeper understanding for the nature of this situation in Turkey.

The main aim of this study was to construct a significant multivariate model with secondary level structural equating modelling which includes relations between students' characteristics and their scientific literacy performance. And then, according to this model, it was aimed to define and interpret the predictive level of these characteristics to the scientific literacy skills of students.

\section{Method}

This study was designed as a correlational research. Secondary level analyses have been performed on PISA 2012 data. Correlational design is the most common non-experimental research design especially in education (Karasar, 2012). In this kind of research, two or more variables are tried to determine whether there is relations between them (Slavin, 1992).

PISA 2012 Turkey population was composed of 955349 fifteen year-old student. PISA 2012 Turkey sample was 
determined based on NUTS Level-1. Sample was composed of 170 schools and totally 4848 students.

\subsection{Data Collection Tool}

In this study, secondary level analyses were conducted on PISA 2012 Turkey student questionnaire data. PISA 2012 student questionnaire was well-structured psychometrically. Trial and pilot applications were done for developing this tool with large student samples from all participant countries and economies. And it was brought under control in terms of validity and reliability (OECD, 2013b).

PISA student questionnaire provides some important information about students' background related with their performance (OECD, 1999, 2014a). PISA 2012 student questionnaire was designed as three patterned forms (Form A, Form B and Form C). In PISA 2012 Turkey application, each form included 10 sections and totally 66 items approximately. These sections were; information about yourselves, information about your family and home, math training, math and/or problem solving experiences, your school, ICT availability, general computer use, ICT use out of school, ICT use at school, attitudes towards computer use. Unlike other participants, Turkey questionnaire included some items of ICT use and familiarity of ICT. There were some common items within each section (like sex, age, country of birth, language spoken at home, parents' occupations and educations, cultural and material possessions, and etc.) in each form. General structure of these kinds of questions was categorical. Students were asked to select and mark appropriate and available choice for their selves. On the other hand, there were some other information about students' characteristics (like attitudes toward school, sense of belonging, interest in the main domain, perseverance, ICT use, attitudes for computer use, and etc.) in just two of these three forms. General structure of these kinds of questions groups was 4 or 5 graded scales. Students were asked to mark the level of their situations or opinions for given statements. After cognitive tests, students were given 30 minutes to answer the questions (MEB, 2015).

\subsection{Analysis of Data}

Within the aim of this study, a secondary-level structural model was developed by using PISA indexes and standard scores and variables identified from student questionnaire data. On this model, students' scientific literacy performances were determined as secondary-level latent variables. Students' characteristics were determined as primary-level observed variables. During the analyses, it was utilized from IBM SPSS Statistics 20 and LISREL 8.7 software.

\section{Results}

This section includes findings about processes of constructing the model, and predictive level of students' characteristics to their scientific literacy skills.

\subsection{Selecting Variables for Initial Model}

PISA 2012 student questionnaire data set includes nearly 50 continuous variables as indexes and standard scores. These variables represent student characteristics as mentioned before. In this study, to select variables for initial models, at first, all these continuous variables in the PISA 2012 Turkey Student Questionnaire data was examined with detailed. Some of these variables were not available for Turkey (like future orientation, language background, cultural distance and heritage, information about Labour Market, etc.). So, 29 variables could be determined for initial model.

Selected variables were analysed in terms of basic assumptions. Variables were checked for missing data, outliers and autocorrelations. It is seen that ratio of missing is under 5 percent for each variable. Assuming that the missing data were formed randomly, expectation-maximization algorithms as the missing data method was used to handle with missing data problem and to obtain a complete data set. There is very small amount of outliers for each variable (under 1 percent) and there is no autocorrelation problem. In addition to these preliminary studies, normality was checked by graphically and descriptively. Linearity was checked by calculating bivariate and partial correlation coefficients. Also, multicollinearity was checked by calculating variance inflation factors, tolerance coefficients and condition index as collinearity diagnostics statistics. According to these analyses, it was seen that some of these 29 variables did not meet some assumptions. These variables were marked for further analyses.

\subsection{Constructing the Primary Level Model}

After checking basic assumptions, principal component analysis with oblique rotation was conducted with these 29 selected variables. Data set is available for this analysis $(\mathrm{KMO}=0.853$, Bartlett's test of sphericity $\chi 2=139958.13, \mathrm{df}=406$ and $\mathrm{p}<0.05)$. At the end of exploratory analyses, 12 variables were defined under three factors. Total variance explained and structure matrix and correlations between factors are shown in the 
following tables.

Table 1. Total variance explained by factors

\begin{tabular}{lcccc}
\hline Factors & Eigenvalues & Rotated Eigenvalues & Variance (\%) & Cumulative Variance (\%) \\
\hline \multirow{2}{*}{4.293} & 4.292 & 35.771 & 35.771 \\
3 & 2.692 & 2.317 & 22.434 & 58.205 \\
\hline
\end{tabular}

* Factors with eigenvalues above 1.00 are shown in the table.

Table 2. Structure matrix with variables and factors

\begin{tabular}{|c|c|c|c|c|}
\hline \multirow{2}{*}{ Variables/Characteristics } & \multirow{2}{*}{ Symbol } & \multicolumn{3}{|c|}{ Factors } \\
\hline & & 1 & 2 & 3 \\
\hline Home Possessions & HOMEPOS & .947 & & \\
\hline Wealth & WEALTH & .893 & & \\
\hline Index of economic, social and cultural status & ESCS & .887 & & \\
\hline Home educational resources & HEDRES & .805 & & \\
\hline ICT Availability at Home & ICTHOME & .798 & & \\
\hline Highest parental education in years & PARED & .690 & & \\
\hline Teacher Behaviour: Formative Assessment & TCHBEHFA & & .895 & \\
\hline Teacher Behaviour: Teacher-directed Instruction & TCHBEHTD & & .828 & \\
\hline Teacher Behaviour: Student Orientation & TCHBEHSO & & .823 & \\
\hline Attitude towards School: Learning Outcomes & ATSCHL & & & .835 \\
\hline Sense of Belonging to School & BELONG & & & .796 \\
\hline Attitude towards School: Learning Activities & ATTLNACT & & & .755 \\
\hline
\end{tabular}

* Highest factor loadings are shown in the table.

Table 3. Correlations between factors

\begin{tabular}{lccc}
\hline Factors & 1 & 2 & 3 \\
\hline 1 & 1.000 & -.023 & .007 \\
2 & -.023 & 1.000 & .245 \\
3 & .007 & .245 & 1.000 \\
\hline
\end{tabular}

Outputs of exploratory studies, it is seen that a significant model is possible to structure with twelve affective variables. Communalities as extraction for these variables vary between 0.484 and 0.898 . These variables can be grouped under three factors. Total variance explained is 70.6 percent. Correlations between factors are quite a low level. First factor includes six variables, and other factors include three variables. Factors are named as 'socio-economic status (SES)', 'opinions for teachers (OPT)' and 'attitudes for school (ATS)' respectively.

After exploratory studies, confirmatory analyses were conducted on these three factors model. For this purpose, confirmatory factor analysis was conducted with primary level structural equation modeling. Modification indices was considered to improve model-data fit. According to the results, this primary level model is statistically significant $\left(\chi^{2}=718.64, \mathrm{df}=41\right.$ and $\left.\mathrm{p}<0.05\right)$. Some goodness of fit statistics is shown in the following table. 
Table 4. Goodness of fit statistics for Primary Level Structural Model

\begin{tabular}{lc}
\hline Indices & Statistics \\
\hline Root Mean Square Error of Approximation (RMSEA) & 0.06 \\
Root Mean Square Residual (RMR) & 0.09 \\
Standardized RMR & 0.06 \\
Normed Fit Index (NFI) & 0.98 \\
Non-Normed Fit Index (NNFI) & 0.97 \\
Comparative Fit Index (CFI) & 0.98 \\
Incremental Fit Index (IFI) & 0.98 \\
Relative Fit Index (RFI) & 0.97 \\
Goodness of Fit Index (GFI) & 0.98 \\
Adjusted Goodness of Fit Index (AGFI) & 0.95 \\
Parsimony Goodness of Fit Index (PGFI) & 0.51 \\
\hline
\end{tabular}

* All statistics are significant at 0.01 significance level.

According to the results, it is seen that a primary level model with twelve variables and three factors can be confirmed statistically. Although residuals are not support the model-data fit with perfect level, this model is statistically significant and shows high model-data fit.

\subsection{Constructing the Secondary Level Model}

After confirmatory studies, secondary level modelling was tried to construct by adding 'science literacy skills (SLS)' as a secondary level latent variable to the primary level model. Plausible values for science literacy performance (PV_SCIE) were associated with the SLS. Conceptual diagram for this model is shown in following figure.

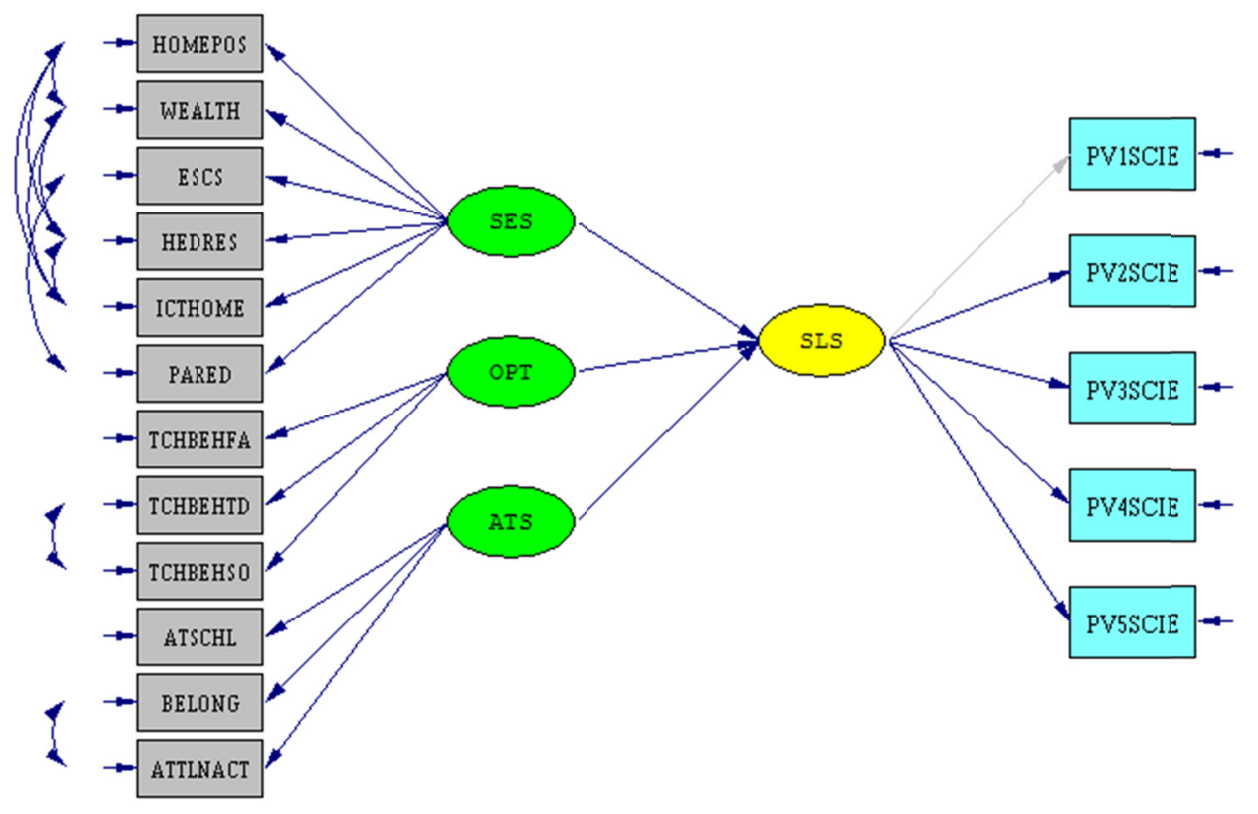

Figure 1. Secondary level conceptual diagram

Analysis was conducted by considering possible modifications to improve model-data fit. According to the results, a significant secondary level model could be constructed $\left(\chi^{2}=1766.68, \mathrm{df}=104\right.$ and $\left.\mathrm{p}<0.05\right)$. Some 
goodness of fit statistics is shown in the following table.

Table 5. Goodness of fit statistics for Secondary Level Structural Model

\begin{tabular}{lc}
\hline Indices & Statistics \\
\hline Root Mean Square Error of Approximation (RMSEA) & 0.06 \\
Standardized RMR & 0.07 \\
Normed Fit Index (NFI) & 0.98 \\
Non-Normed Fit Index (NNFI) & 0.98 \\
Comparative Fit Index (CFI) & 0.98 \\
Incremental Fit Index (IFI) & 0.98 \\
Relative Fit Index (RFI) & 0.97 \\
Goodness of Fit Index (GFI) & 0.96 \\
Adjusted Goodness of Fit Index (AGFI) & 0.94 \\
Parsimony Goodness of Fit Index (PGFI) & 0.65 \\
\hline
\end{tabular}

* All statistics are significant at 0.01 significance level.

As shown in table, the secondary level model fits very-well. Indices for residuals are below 0.05 and other indices are above 0.95 generally.

\subsection{Predictive Level of Students' Characteristics}

According to the secondary level structural model, it is possible to make inference about the predictive level of students' characteristics and best predictor for their scientific literacy skills. Standardized coefficients for paths in the model are shown in the following table.

Table 6. Standardized coefficients for paths in the Secondary Level Structural Model

\begin{tabular}{llcccc}
\hline $\begin{array}{l}\text { Error } \\
\text { Terms }\end{array}$ & Indicators & Estimates & $\begin{array}{c}\text { Primary Level Latent } \\
\text { Variables }\end{array}$ & Estimates & $\begin{array}{c}\text { Secondary Level Latent } \\
\text { Variable }\end{array}$ \\
\hline 0.19 & HOMEPOS & 0.90 & & & \\
0.31 & WEALTH & 0.83 & SES & 0.37 & \\
0.28 & ESCS & 0.85 & & & SLS \\
0.48 & HEDRES & 0.72 & & & \\
0.55 & ICTHOME & 0.67 & & & \\
0.69 & PARED & 0.55 & OPT & & \\
\hline 0.41 & TCHBEHFA & 0.77 & & & \\
0.19 & TCHBEHTD & 0.90 & & 0.18 & \\
0.41 & TCHBEHSO & 0.77 & ATS & & \\
\hline 0.62 & ATSCHL & 0.62 & & & \\
0.31 & BELONG & 0.83 & & & \\
0.43 & ATTLNACT & 0.76 & & & \\
\hline
\end{tabular}

* All paths are significant $(\mathrm{t}>2.34$ and $\mathrm{p}<0.05)$.

As shown in table, among three primary level latent variables or factors, 'socio-economic status' is the best predictor of scientific literacy skills. One-unit change in this variable leads 0.37 unit change in 'scientific literacy skills'.

'Opinions for teacher' is second predictive factor and negatively correlated with 'scientific literacy skills'. 
One-unit change in this variable leads -0.18 unit change in 'scientific literacy skills'. Indicators related with them are negatively correlated with 'scientific literacy skills' as well. This finding means that students with positive opinions to their teachers have lower level of 'scientific literacy skills'. Also, opposite is true.

'Attitudes for school' is the third predictive factor and positively correlated with 'scientific literacy skills'. One-unit change in this variable leads 0.10 unit change in 'scientific literacy skills'.

Among observed variables or indicators, 'home possessions' is the best predictors of 'scientific literacy skills' $(0.90 \times 0.37=0.3330)$. One-unit change in 'home possessions' leads 0.90 unit change in 'socio-economic status' and 0.33 unit change in 'scientific literacy skills'. It is followed by 'index of economic, social and cultural status' $(0.85 \times 0.37=0.3145)$ and 'wealth' $(0.83 \times 0.37=0.3071)$.

On the other hand, lowest predictors among indicators are 'attitude towards school: learning outcomes' $(0.62 \times 0.1=0.062)$, 'attitude towards school: learning activities' $(0.76 \times 0.1=0.076)$ and 'sense of belonging to school' $(0.83 \times 0.1=0.083)$ respectively. One-unit changes in these characteristics lead $0.062,0.076$ and -0.083 unit change in 'scientific literacy skills'.

\section{Discussion, Conclusion and Suggestions}

Findings of this study show that there are complex and multifactorial and significant relations between fifteen year-old student's characteristics and scientific literacy skills in Turkey. According to this it's possible to predict students' success and achievement by observing their characteristics. There are some other studies that the similar relations and findings have been observed (Abu-Hilal, 2000; An1l, 2009, 2011; Özer \& An1l, 2011; Acar, 2012; Ceylan \& Abac1, 2013; MEB, 2015).

These kinds of multifactorial relations can be modelled on a multivariate structure. For such a model, PISA provides important advantages. PISA data includes many variables for students' characteristics related with scientific literacy skills. It is difficult to find such kind of data together. However, multivariate statistical models, like structural equation models, are expected to meet some certain assumptions (like normality, linearity, stability of variance, etc.). Therefore, such models are statistically limited and hard to create. Processes for selecting variables and constructing the model should be conducted fairly sensitive. Moreover, each model just can be significant in its own limitations.

In this study, a secondary level structural equation model could be constructed significantly. In this model, relations between students' characteristics and scientific literacy skills, in Turkey, were modelled in multivariate level. This model is statistically significant with high model-data fit. As students' characteristics, 12 indicators were determined in the model. These observed variables were defined under three factors. These factors were named as 'socio-economic status', 'opinions for teachers' and 'attitudes for school' respectively.

Limitations of the model, among factors, best predictor of scientific literacy skills are 'socio-economic status'. These latent variables are defined with 'home possessions', 'wealth', 'index of economic, social and cultural status', 'home educational resources', 'ICT availability at home' and 'highest parental education in years'. It is seen that students with high level of 'socio-economic status' in the context of these observed variables have high level of scientific literacy skills. Also opposite is true. Similarly, Özer and Anıl (2011) found that there were significant correlation between students' scientific literacy skills and parent education level and educational resources. These characteristics are also the part of socioeconomic status of the students.

Students' 'opinions for teacher' shows negative correlation with scientific literacy skills. This factor was defined with opinions for 'teacher behaviours'. Accordingly, students with positive opinions for their teachers have lower level of scientific literacy skills. Also opposite is true. This findings show the possibility of teachers' negative effect to the performance of the students. Of course, there is need for in-depth research on these issues. There are some other studies that support this finding. For example, Acar (2012) found that teacher's role and their positions were able to affect students' success. Similarly, Telli, Brok and Çakıroğlu observed that there was a significant correlation between teacher-student relationships and students' attitudes toward sciences.

As another finding in this study, students' 'attitudes towards school' have low but positive correlation with scientific literacy skills. This means that students with positive attitudes toward school have also high level of 'scientific literacy skills'. It's well known for a long time that there is significant correlation between achievement and attitude (Brodie Jr, 1964; Morrell \& Lederman, 1998; Osborne, Simon, \& Collins, 2003). Also, there are some other studies that support this finding. For example, German (1988) observed that there was significant but low correlation between attitudes toward science and students' achievement. This situation was related with education quality. More recently, according to the MEB report (2015), it was observed some negative correlation between some student characteristics and their achievement level of math in Turkey. These 
findings were interpreted as a reduction of the importance of schools.

As another finding in this study, among indicators, best predictor of scientific literacy skills is 'home possessions'. It is followed by 'index of economic, social and cultural status' and 'wealth'. Lowest predictors among indicators are 'attitude towards school: learning outcomes', 'attitude towards school: learning activities' and 'sense of belonging to school' respectively. All these variables are positively correlated with scientific literacy skills.

In order to support the development of students effectively, it is important to understand the nature of such kind of relations. In the teaching-learning process, improvements to be made in accordance with these characteristics would likely to raise and improve students' performances.

For further research, it is recommended that other domains like mathematical literacy should be considered. As another recommendation, it is thought that different structural models can be constructed with different variables. In addition, a comparative study between different cultures is recommended.

\section{References}

Abu-Hilal, M. M. (2000). A Structural Model of Attitudes Towards School Subjects, Academic Aspiration and Achievement. Educational Psychology: An International Journal of Experimental Educational Psychology, 20(1), 75-84.

Acar, T. (2012). 2009 Yılı Uluslararası Öğrenci Başarılarını Değerlendirme Programında Türk Öğrencilerin Başarılarını Etkileyen Faktörler. Eğitimde ve Psikolojide Ölçme ve Değerlendirme Dergisi (EPOD), 3(2), 309-314.

Anıl, D. (2009). Uluslararası Öğrenci Başarılarını Değerlendirme Programı (PISA)'nda Türkiye'deki Öğrencilerin Fen Bilimleri Başarılarını Etkileyen Faktörler. Education and Science, 34(152), 87-100.

Anıl, D. (2011). Türkiye'nin PISA 2006 Fen Bilimleri Başarısını Etkileyen Faktörlerin Yapısal Eşitlik Modeli ile İncelenmesi. Educational Sciences: Theory \& Practice, 11(3), 1253-1266.

Atwater, M. M., Wiggins, J., \& Gardner, C.M. (2006). A Study of Urban Middle School Student with High and Low Attitudes toward Science. Journal of Research in Science Teaching, 32(6), 665-677.

Brodie Jr., T. A. (1964). Attitude toward school and academic achievement. Personnel \& Guidance Journal, 43(4), 375-378.

Ceylan, E., \& Abac1, S. (2013). Differences between Turkey and Finland based on Eight Latent Variables in PISA 2006. International Online Journal of Educational Sciences, 5(1), 10-21.

DeBoer, G. E. (2000). Scientific Literacy: Another Look at Its Historical and Contemporary Meanings and Its Relationship to Science Education Reform. Journal of Research in Science Teaching, 37(6), 582-601.

German, P. J. (1988). Development of the attitude toward science in school assessment and its use to investigate the relationship between science achievement and attitude toward science in school. Journal of Research in Scinece Teaching, 25(8), 689-703.

Halbrok, J., \& Rannikmae, M. (2009). The Meaning of Scientific Literacy. International Journal of Environmental \& Science Education, 4(3), 275-288.

Karasar, N. (2014). Bilimsel Araştırma Yöntemi (27. Baskl). Ankara: Nobel Akademik Yayıncılık.

Luu, K., \& Freeman, J. G. (2010). An analysis of the relationship between information and communication technology (ICT) and scientific literacy in Canada and Australia. Computers \& Education, 56(4), 1072-1082.

McFarlane, D. A. (2013). Understanding the Challenges of Science Education in the $21^{\text {st }}$ Century: New Opportunities for Scientific Literacy. International Letters of Social and Humanistic Sciences, 4, 35-44.

MEB. (2015). PISA 2012 Türkiye Ulusal Nihai Raporu. Ankara: T.C. Millî Eğitim Bakanlığı Yayınları. Retrieved February 28, 2016 from http://pisa.meb.gov.tr/?page_id=22

Morrell, P. D., \& Lederman, N. G. (1998). Student's Attitudes Toward School and Classroom Science: Are They Independent Phenomena? School Science and Mathematics, 98(2), 76-83.

OECD. (1999). Measuring Student Knowledge and Skills: A New Framework for Assessment. OECD Publishing. Retrieved March 29, 2015, from http://www.oecd.org/edu/school/programmeforinternationalstudentassessmentpisa/33693997.pdf 
OECD. (2003). The PISA 2003 Assessment Framework. OECD Publishing. Retrieved March 29, 2015, from http://www.pisa.oecd.org/dataoecd/46/14/33694881.pdf

OECD. (2009a). PISA 2009 Assessment Framework: Key competencies in reading, mathematics and science. OECD Publishing. Retrieved March 29, 2015, from http://www.oecd.org/pisa/pisaproducts/44455820.pdf

OECD. (2009b). "What can students do in science?" in Highlights from Education at a Glance 2008. OECD Publishing. Retrieved March 29, 2015, from http://www.oecd-ilibrary.org/docserver/download/ 9609011 ec034.pdf?expires=1427666530\&id=id\&accname= guest\&checksum=63E26465D97336181B1FA7 AC06E7BFEB

OECD. (2013a). PISA 2015 Draft Science Framework. OECD Publishing. Retrieved March 29, 2015, from http://www.oecd.org/pisa/pisaproducts/Draft\%20PISA\%202015\%20Science\%20Framework\%20.pdf

OECD. (2013b). PISA 2012 Assessment and Analytical Framework: Mathematics, Reading, Science, Problem Solving and Financial Literacy. OECD Publishing. http://dx.doi.org/10.1787/9789264190511-en

OECD. (2014a). PISA 2012 Technical Report. OECD Publishing. Retrieved March 29, 2015, form http://www.oecd.org/pisa/pisaproducts/PISA-2012-technical-report-final.pdf

OECD. (2014b). PISA 2012 Results in Focus: What 15-year-olds know and what they can do with what they know (Volume I). OECD Publishing. Retrieved March 29, 2015, form http://www.oecd.org/pisa/keyfindings/pisa-2012-results-overview.pdf

Osborne, J., Simon, S., \& Collins, S. (2003). Attitudes towards science: A review of the literature and its implications. International Journal of Science Education, 25(9), 1049-1079.

Özer, Y., \& Anıl, D. (2011). Öğrencilerin Fen ve Matematik Başarılarını Etkileyen Faktörlerin Yapısal Eşitlik Modellemesi ile İncelenmesi. Hacettepe University Journal of Education, 41, 313-324.

Slavin, R. E. (1992). Research Methods in Education (2nd ed.). Needham Heights, MA: Allyn \& Bacon.

Telli, S., Brok, P., \& Çakıroğlu, J. (2010). The importance of teacher-student interpersonal relationships for Turkish students' attitudes towards science. Research in Science \& Technological Education, 28(3), 261-276.

Watters J. J., \& Ginns, I. S. (2000). Developing Motivation to Teach Elementary Science: Effect of Collaborative and Authentic Learning Practices in Preservice Education. Journal of Science Teacher Education, 11(4), 277-313.

\section{Copyrights}

Copyright for this article is retained by the author(s), with first publication rights granted to the journal.

This is an open-access article distributed under the terms and conditions of the Creative Commons Attribution license (http://creativecommons.org/licenses/by/3.0/). 